\title{
Review Article \\ Tumor Necrosis Factor Alpha: A Link between Neuroinflammation and Excitotoxicity
}

\author{
Gabriel Olmos and Jerònia Lladó \\ Grup de Neurobiologia Cel-lular, Departament de Biologia and Institut Universitari d'Investigacions en Ciències de la Salut, IUNICS, \\ Universitat de les Illes Balears, 07122 Palma de Mallorca, Spain
}

Correspondence should be addressed to Gabriel Olmos; gabriel.olmos@uib.es

Received 13 February 2014; Accepted 7 May 2014; Published 21 May 2014

Academic Editor: Agueda A. Rostagno

Copyright (C) 2014 G. Olmos and J. Lladó. This is an open access article distributed under the Creative Commons Attribution License, which permits unrestricted use, distribution, and reproduction in any medium, provided the original work is properly cited.

\begin{abstract}
Tumor necrosis factor alpha (TNF- $\alpha$ ) is a proinflammatory cytokine that exerts both homeostatic and pathophysiological roles in the central nervous system. In pathological conditions, microglia release large amounts of TNF- $\alpha$; this de novo production of TNF- $\alpha$ is an important component of the so-called neuroinflammatory response that is associated with several neurological disorders. In addition, TNF- $\alpha$ can potentiate glutamate-mediated cytotoxicity by two complementary mechanisms: indirectly, by inhibiting glutamate transport on astrocytes, and directly, by rapidly triggering the surface expression of $\mathrm{Ca}^{+2}$ permeable-AMPA receptors and NMDA receptors, while decreasing inhibitory $\mathrm{GABA}_{\mathrm{A}}$ receptors on neurons. Thus, the net effect of TNF- $\alpha$ is to alter the balance of excitation and inhibition resulting in a higher synaptic excitatory/inhibitory ratio. This review summarizes the current knowledge of the cellular and molecular mechanisms by which TNF- $\alpha$ links the neuroinflammatory and excitotoxic processes that occur in several neurodegenerative diseases, but with a special emphasis on amyotrophic lateral sclerosis (ALS). As microglial activation and upregulation of TNF- $\alpha$ expression is a common feature of several CNS diseases, as well as chronic opioid exposure and neuropathic pain, modulating TNF- $\alpha$ signaling may represent a valuable target for intervention.
\end{abstract}

\section{Introduction}

Tumor necrosis factor alpha (TNF- $\alpha$ ) was originally identified as a factor that leads to rapid necrosis of transplantable tumors in mice [1] and now it is considered a proinflammatory cytokine involved in the innate immune response [2]. In the central nervous system (CNS) TNF- $\alpha$ exerts both homeostatic and pathophysiological roles [3, 4] In the healthy CNS TNF- $\alpha$ has regulatory functions on crucial physiological processes such as synaptic plasticity $[5,6]$, learning and memory [7, 8], sleep [9], food and water intake [10], and astrocyte-induced synaptic strengthening [11]. In pathological conditions, astrocytes and mainly microglia release large amounts of TNF- $\alpha$; this de novo production of this cytokine is an important component of the so-called neuroinflammatory response that is associated with several neurological disorders [3, 12-14]. In addition, TNF- $\alpha$ can potentiate glutamate-mediated cytotoxicity by two complementary mechanisms: indirectly, by inhibiting glutamate transport on astrocytes, and directly, by increasing the localization of ionotropic glutamate receptors to synapses [15]. Neuroinflammation and excitotoxicity have key roles as triggers and sustainers of the neurodegenerative process and thus, elevated levels of TNF- $\alpha$ have been found in traumatic brain injury [16], ischemia [17, 18], Alzheimer's disease (AD) $[19,20]$, Parkinson's disease (PD) [21, 22], multiple sclerosis (MS) $[23,24]$, and amyotrophic lateral sclerosis (ALS) $[25,26]$. This review summarizes the current knowledge of the cellular and molecular mechanisms by which TNF- $\alpha$ potentiates excitotoxicity and describes its key role in linking the neuroinflammatory and excitotoxic processes that take place not only in ALS but also in other common neurodegenerative diseases.

\section{TNF- $\alpha$ Signaling}

TNF- $\alpha$ is first synthesized as a transmembrane protein $(\operatorname{tmTNF}-\alpha)$. The cleavage of the extracellular domain of 
tmTNF- $\alpha$ by the matrix metalloprotease TNF- $\alpha$-converting enzyme (TACE) releases a soluble TNF- $\alpha$ (sTNF- $\alpha)$ homotrimer. Remarkably, both tmTNF- $\alpha$ and sTNF- $\alpha$ are biologically active and their signal transduction involves binding to two distinct surface receptors, TNF- $\alpha$ receptor 1 (TNFR1 or p55TNFR) and TNF- $\alpha$ receptor 2 (TNFR2 or p75TNFR), which are different in their expression pattern, downstream signal-transduction cascades, and binding affinity for TNF- $\alpha$ [27-29]. The cytoplasmic tail of TNFR1 contains a death domain; however, this motif is missing in TNFR2. Although initially it was considered that TNFR1 activation was involved in the cytotoxic and apoptotic effects of TNF- $\alpha$, and those related to cell survival and proliferation involved TNFR2 activation, now it is becoming clear that TNFR2 can also induce cell death [30]. Binding of the TNF- $\alpha$ trimer to the extracellular domain of TNFR1 induces receptor trimerization and recruitment of the adaptor protein TNF receptor-associated death domain (TRADD), which in turn recruits additional adaptor proteins: receptor-interacting protein (RIP), TNF receptor-associated factor 2 (TRAF2), and Fas-associated death domain (FADD). This latter protein mediates recruitment and activation of caspases 8 and 10 that initiate a protease cascade that leads to apoptosis [31]. TNFR1 signaling also results in the activation of the following signal transduction pathways: the nuclear factor-kappa B $(\mathrm{NF}-\kappa \mathrm{B})$, the extracellular signal-regulated kinase (ERK), the c-Jun N-terminal kinase (JNK), the p38 mitogen-activated protein kinase (p38 MAPK), the acidic sphingomyelinase (A-SMase), and the neutral sphingomyelinase (N-SMase) pathways. These pathways regulate the expression of several genes, and some of them, particularly those regulated by the NF- $\kappa \mathrm{B}$ pathway, have antiapoptotic effects. With the exception of the SMase pathways, the above signal transduction pathways can also be induced through TNFR2 signaling because TRAF2 (along with TRAF1) can directly associate to the intracellular domain of the TNFR2 receptor (reviewed by $[32,33]$ ).

\section{TNF- $\alpha$ and Neuroinflammation}

Neuroinflammation in the CNS refers to the collective response of microglia, and to a lesser extent of astrocytes and oligodendrocytes, against diverse insults (invading pathogens, trauma, aggregated or modified proteins, stroke, etc.) designed to remove or inactivate the noxious agents and to inhibit and reverse their detrimental effects. The glial response can be considered as an innate immune mechanism, whereas the participation in the neuroinflammatory process of lymphocytes (mainly T cells) carrying binding sites for specific antigens is an acquired immune mechanism [14]. In neurodegenerative diseases, both innate and acquired immune mechanisms are unable to resolve the triggers, creating a self-sustaining environment where the neuroinflammation persists, thus leading to a chronic neuroinflammation.

Although astrocytes and neurons are able to produce TNF- $\alpha$ [34-36], it is assumed that microglia are the major source of this cytokine during neuroinflammation [37, 38]. The cytokine interferon gamma (IFN- $\gamma$ ) is a potent inducer of TNF- $\alpha$ gene expression in microglia [38-40], and also it upregulates the expression of adhesion/costimulatory molecules, like the major histocompatibility complex (MHC) class II molecules to sustain antigen-dependent T-cell activation $[41,42]$. The different inflammatory stimuli that activate microglia during neuroinflammation trigger different signaling pathways including p $38 \mathrm{MAPK}, \mathrm{JNK}, \mathrm{NF}-\kappa \mathrm{B}$, and ERK1/2 [43-46], making it difficult to determine which of them is in fact implicated in the induction of TNF- $\alpha$ expression. In our laboratory, we demonstrated that the sole inhibition of the mitogen-activated protein kinase and ERK kinase (MEK)/ERK signaling pathway with U0126 or apigenin was enough to inhibit the LPS or the IFN- $\gamma$-stimulated TNF- $\alpha$ expression in the BV-2 microglial cell line [47]. Similar results had been previously published in human monocytes [48]. As IFN- $\gamma$ is produced by $\mathrm{T}$ cells but not in significant amounts by any CNS resident cells, including microglia $[49,50]$, it has been proposed that, in neurodegenerative diseases, activated T cells would infiltrate into the parenchyma of the CNS [5154] releasing their own inflammatory mediators, including IFN- $\gamma[55,56]$. In this sense, in ALS, lymphocytic infiltrates and antibody deposits were detected in postmortem CNS tissues [57] and, more recently, increased $\mathrm{CD} 4^{+}$and $\mathrm{CD} 8^{+} \mathrm{T}$ cells were found to invade the brain in postmortem human specimens and in a mouse model of PD [58]. Although the role of the infiltrated T cells in the CNS is controversial, since both $\mathrm{CD}^{+}$and $\mathrm{CD}^{+} \mathrm{T}$ cells can have detrimental [59] or protective effects [60-62], it may be proposed that, during the neuroinflammatory process, these infiltrated cells release the cytokine IFN- $\gamma$ which, via the MEK/ERK signaling pathway, induces in microglia an increased de novo TNF- $\alpha$ production and release (Figure 1). However, T cells may not be present in the CNS at early disease stages; for example, in ALS, $\mathrm{T}$ cells infiltrate the spinal cord as disease progresses [63]. Thus, microglia can be activated to release TNF- $\alpha$ at early asymptomatic disease stages by sensing the earliest neuronal stress and later, infiltrated T cells releasing IFN- $\gamma$ would keep microglia in an active state $[64,65]$.

These findings indicate that IFN- $\gamma$ and TNF- $\alpha$ have key roles in the glial-T-cell dialogue that occurs during neuroinflammation, as they are involved in T-cell adhesion to endothelial cells, extravasation, and T-cell and glial activation [54]. In this regard, we have demonstrated that IFN- $\gamma$ and TNF- $\alpha$ have complementary roles in inducible microglial nitric oxide generation [47] and that both cytokines, through the induction of the expression of several prooxidative enzymes, cooperatively induce oxidative stress and motoneuron death [66].

\section{TNF- $\alpha$ and Excitotoxicity}

Glutamate is the main excitatory neurotransmitter in the mammalian CNS and is involved in many aspects of normal brain function [67]. Excitotoxicity refers to a process of neuronal death caused by excessive or prolonged activation of receptors for this excitatory amino acid [68]. A role for excitotoxicity in the aetiology or progression of many human acute or chronic neurodegenerative diseases, including ischemia, $\mathrm{AD}, \mathrm{PD}, \mathrm{MS}$, and ALS has been proposed (reviewed by [69]). 
The first reports demonstrating that TNF- $\alpha$ was able to potentiate excitotoxicity were performed in human neuronal cultures. Gelbard et al. demonstrated that subtoxic doses of both TNF- $\alpha$ and $\alpha$-amino-3-hydroxy-5-methyl4-isoxazolepropionic acid (AMPA) were neurotoxic when combined [70]. Similar results were published one year later showing that TNF- $\alpha$ potentiated glutamate neurotoxicity and that this effect could be blocked by competitive (2-APV) and noncompetitive (MK-801) NMDA receptor antagonists [71]. Later, and by working on rat spinal cord, it was demonstrated that nanoinjections of nontoxic doses of either TNF- $\alpha$ or kainate (KA) alone into the thoracic gray matter resulted in almost no tissue damage; however, the combination of these substances at the same doses produced a large area of tissue necrosis and neuronal cell death, an effect that could be reverted by the AMPA receptor antagonist 6-cyano-7nitroquinoxaline 2,3-(1H,4H)-dione (CNQX) [72].

\section{Potentiation of Excitotoxicity by TNF- $\alpha$ : Role of Glial Cells}

After the above previous works, the role of glial cells in TNF- $\alpha$ induced neuronal death was investigated. In mouse primary microglia it was demonstrated that TNF- $\alpha$, through the TNFR1 pathway, induces excitotoxicity by promoting microglial glutamate release from hemichannels of gap junctions in an autocrine manner [73]. Moreover, in rat primary microglia it was found that agonist stimulation of group 2 metabotropic glutamate receptors (mGluR2) induced TNF- $\alpha$ release, and when this microglial-conditioned medium was added to cerebellar granule neurons in culture resulted in caspase- 3 activation and apoptotic cell death. The authors also identified microglial-released Fas ligand as an essential cofactor for the TNF- $\alpha$-induced neurotoxicity [74]. Similar results were obtained on hippocampal neurons where TNF- $\alpha$ derived from KA-activated microglia also resulted in apoptotic neuronal cell death [75]. Thus, two potential microglial autocrine loops participating in excitotoxicity can be identified: first, TNF- $\alpha$ promotes further microglial TNF- $\alpha$ production and release through TNFR1 signaling [76] and second, TNF- $\alpha$ induces glutamate release that acts on microglial mGluR2 to induce more TNF- $\alpha$ production (Figure 1).

In astroglia, the interaction of TNF- $\alpha$ with TNFR1 initiates a sequence of intracellular signaling events that leads to generation of prostaglandin $\mathrm{E}_{2}$ that, in turn, activates the elevation of intracellular calcium followed by glutamate exocytosis $[77,78]$. The excessive glutamate concentrations resulting from TNF- $\alpha$ stimulation of astroglial and microglial TNFR1 could be diminished by the glutamate uptake system $[79,80]$; however, TNF- $\alpha$ has a detrimental effect on astroglial glutamate uptake (reviewed by [81]) (Figure 1). At least five sodium-dependent glutamate transporters have been cloned. The transporters (human/rat) EAAT1/GLAST and EAAT2/GLT-1 are predominantly located on astrocytes and GLT-1 is the most abundant glutamate transporter in the adult brain $[82,83]$. In human $\mathrm{H} 4$ astroglioma cells and rat astrocytes, it has been shown that exposure for four to six hours to TNF- $\alpha$ (10 or $20 \mathrm{ng} / \mathrm{mL}$ ) inhibits glutamate uptake by inducing a downregulation of EAAT2/GLT-1 mRNA [84, 85]. In $\mathrm{H} 4$ astroglioma cells, downregulation of EAAT2 was dependent on the TNF- $\alpha$ induced binding of NF- $\kappa$ B to the EAAT2 promoter [84]. The role of NF- $\kappa \mathrm{B}$ in regulating GLT-1 expression was further confirmed in our laboratory. We used spinal cord organotypic cultures to create a model of chronic glutamate excitotoxicity in which glutamate transporters were inhibited by threohydroxyaspartate (THA) to induce motoneuron death. Exposure to THA induced microglial activation and TNF- $\alpha$ release. In the presence of exogenous TNF- $\alpha$ (20 ng/mL), THA-induced excitotoxic motoneuron death was potentiated. Coexposure to TNF- $\alpha$ and THA also resulted in downregulation of GLT-1 and in increased extracellular glutamate levels. The downregulation of GLT1 , as well as the excitotoxic motoneuron death, could be prevented by NF- $\kappa$ B inhibition [86].

When TNF- $\alpha(20 \mathrm{ng} / \mathrm{mL})$ was applied for a short time period (30 minutes) in hippocampal-entorhinal complex slice cultures, it reduced glutamate transport without affecting GLT-1 or GLAST expression [87]. The mechanisms of this rapid, and apparently, nongenomic effect of TNF- $\alpha$ are not clear. On the one hand, TNF- $\alpha$ is a clear inducer of oxidative stress in the CNS $[66,88,89]$, and evidences indicate that glutamate transporters are vulnerable to the action of reactive oxygen and nitrogen species that inhibit glutamate uptake within minutes $[90,91]$, thus providing a link between oxidative stress and excitotoxicity. In addition, reactive oxygen species generated within neurons in response to an excitotoxic insult can pass across the plasma membrane and disrupt glutamate transport in neighboring astrocytes [92]. On the other hand, TNF- $\alpha$, as explained before, can activate caspases, including caspase-3, which can also be activated by oxidative stress [93]. In this sense, caspase- 3 mediated cleavage of GLT-1 results in the inhibition of its activity [94].

It is interesting to note that, in those neurological disorders in which neuroinflammation and increased levels of TNF- $\alpha$ have been described (see Section 1), it has also been reported a reduced expression of GLT-1, GLAST, or both (reviewed by [81]). As an example, in ALS, where neuroinflammation and excitotoxicity are fundamental mechanisms involved in motoneuron degeneration [65, 95], decreased GLT-1 expression has been reported both in patients [96] and rat models [97, 98]. Moreover, the intrathecal injection of cerebrospinal fluid from ALS patients in the rat spinal cord or the in vitro exposure to this fluid of mixed spinal cord cultures also resulted in a decrease of GLT-1 expression [99].

\section{Potentiation of Excitotoxicity by TNF- $\alpha$ : Modulation of Glutamate and GABA A $_{\mathbf{A}}$ Receptors}

AMPA-type glutamate receptors (AMPARs) are ligand-gated channels that mediate fast excitatory synaptic transmission in the vertebrate CNS. These receptors are tetramers assembled from glutamate receptor (GluR) 1, 2, 3, and 4 (or GluR-A, $-B,-C$, and $-D$ ) subunits around an aqueous pore 


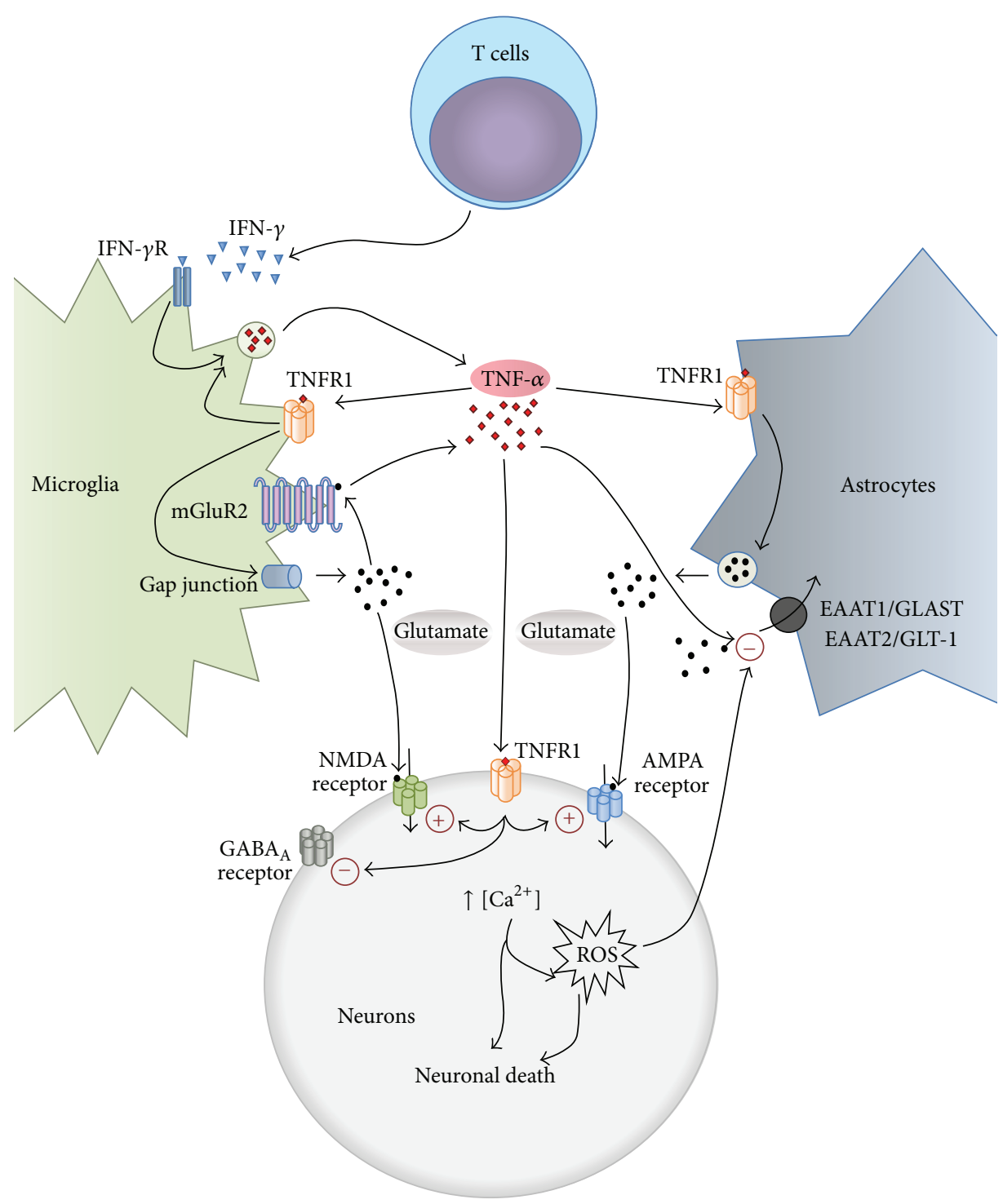

FIGURE 1: Proposed mechanisms by which TNF- $\alpha$ links the neuroinflammatory and the excitotoxic processes. The cytokine IFN- $\gamma$, released by infiltrated T cells, activates TNF- $\alpha$ production and release in microglia. TNF- $\alpha$, through TNFR1 signaling, promotes further microglial TNF$\alpha$ release and also induces glutamate release from hemichannels of gap junctions. In astrocytes, TNF- $\alpha$ stimulates TNFR1 to induce glutamate exocytosis and also inhibits glutamate uptake, thus increasing extracellular glutamate levels. In neurons TNF- $\alpha$, via TNFR1, rapidly increases the excitatory synaptic strength by inducing increased $\mathrm{Ca}^{2+}$ permeable-AMPA receptors and/or NMDA receptors and also decreases the surface expression of inhibitory $\mathrm{GABA}_{\mathrm{A}}$ receptors. The excessive $\mathrm{Ca}^{2+}$ input to neurons induces neuronal death and generates excessive ROS that disrupt glutamate transport in neighboring astrocytes. The dying neurons maintain microglia in an active state, releasing TNF- $\alpha$.

in the membrane $[100,101]$. The trafficking of AMPARs with different subunit composition was initially described in hippocampal CA1 pyramidal cells [102], and now it is generally accepted that such trafficking is critical for the modulation of synaptic strength during learning and memory. Thus, AMPARs trafficking has been implicated in homeostatic synaptic scaling and other forms of longterm synaptic strength adjustments $[4,103,104]$. The GluR2 subunit has a key role in determining the permeability to $\mathrm{Ca}^{2+}$ of AMPARs. GluR2 in combination with other GluR subunits forms channels that are $\mathrm{Ca}^{2+}$-impermeable $[105,106]$. In this regard, in 1997 it was proposed the "GluR2 hypothesis" suggesting that the selective vulnerability of specific neuron populations, described in some neurological disorders, was due to a reduction in the AMPARs expressing the GluR2 subunits, resulting in increased density of $\mathrm{Ca}^{2+}$-permeable AMPARs. The consequent increase in $\mathrm{Ca}^{2+}$ influx through these channels would result in a loss of $\mathrm{Ca}^{2+}$ homeostasis, thus contributing to the delayed neurodegeneration seen in those conditions [107]; see also [108].

TNF- $\alpha$ has an important role in the regulation of AMPARs trafficking being a critical component of the homeostatic regulatory system controlling synaptic plasticity [4]. In 2002, Yu et al. demonstrated that human NT2-N 
neurons exposed to TNF- $\alpha$ increased their expression of the GluR1 subunit, resulting in an increased susceptibility to KA-induced necrosis. The effect of TNF- $\alpha$ implicated both the A-SMase and the NF- $\kappa$ B signaling pathways [109]. Similar results were obtained in hippocampal neurons where TNF- $\alpha$, within $15 \mathrm{~min}$, increased the surface expression of GluR1-containing AMPARs, and these changes were accompanied by dramatic changes in AMPAR-mediated excitatory postsynaptic currents [5]. Later, it was demonstrated a dual role for TNF- $\alpha$ on AMPA-induced excitotoxicity. In mouse hippocampal slice cultures it was reported that pretreatment $(24 \mathrm{~h})$ of cultures with $10 \mathrm{ng} / \mathrm{mL}$ TNF- $\alpha$ potentiated AMPAinduced neuronal death; however, decreasing the concentration of TNF- $\alpha$ to $1 \mathrm{ng} / \mathrm{mL}$ resulted in neuroprotection. The authors demonstrated that the "high-dose" toxic effect was mediated by TNFR1 whereas the "low-dose" protective effect implied the TNFR2 [110]. The role of TNFR1 in the potentiation by TNF- $\alpha$ of AMPA toxicity was further confirmed in a work performed also in hippocampal cells and demonstrating that, by activating neuronal TNFR1, TNF- $\alpha$ increased the surface AMPARs, but remarkably, TNF- $\alpha$ preferentially increased the synaptic expression of GluR2lacking $\left(\mathrm{Ca}^{2+}\right.$ permeable) AMPARs. This effect was mediated through a phosphatidylinositol 3-kinase- (PI3-K-) dependent process [111]. The role of PI3-K in the potentiation by TNF- $\alpha$ of KA-induced neuronal death was confirmed later by the same group; they demonstrated that the specific PI3-K inhibitor LY294002 reverted the TNF- $\alpha$ effect on hippocampal neurons. Moreover, and in agreement with the "GluR2 hypothesis," the potentiating effect was also reverted by the synthetic joro spider toxin analog NASPM, which selectively blocks $\mathrm{Ca}^{2+}$ permeable-AMPARs [112]. These results were also confirmed by others showing that TNF- $\alpha$ triggers a rapid induction of $\mathrm{Ca}^{2+}$ permeable-AMPARs in hippocampal pyramidal neurons; the effect was rapid $(15 \mathrm{~min})$ and since TNF- $\alpha$ exposure did not alter mRNA levels for either GluR1 or GluR2 subunit, it was proposed that TNF- $\alpha$ acts at posttranscriptional level to induce rapid increases in surface subunit expression [113].

The pathological relevance of the above findings was first described in a model of cervical spinal cord contusion injury. In this model, increased synaptic AMPAR numbers were found at synapses ipsilateral to the lesion at $90 \mathrm{~min}$ and $3 \mathrm{~h}$ after injury. Interestingly, in vivo nanoinjections of TNF- $\alpha$ into the ventral horns resulted in increased GluR1 and decreased GluR2 at both extrasynaptic and synaptic plasma membrane sites. The effect was seen in the neuropil $60 \mathrm{~min}$ after TNF- $\alpha$ nanoinjection and could also be detected in the somata of large spinal motoneurons [114]. In a subsequent study, using whole cell recording from lumbar motoneurons, it was demonstrated that both AMPA and NMDA receptor-mediated excitatory postsynaptic currents were rapidly increased following bath application of TNF- $\alpha$ [115]. Together, these results suggested that TNF- $\alpha$ induced GluR2-lacking AMPARs trafficking to the membrane is likely to contribute to postinjury excitotoxicity in spinal cord motoneurons. However, another study has reported
TNF- $\alpha$ to reduce AMPAR-mediated calcium entry in cultured motoneurons by increasing cell surface expression of the GluR2 subunit [116].

Adult spinal cord motoneurons possess significant numbers of $\mathrm{Ca}^{2+}$ permeable-AMPARs under basal conditions, and it has been proposed that this circumstance would render them more susceptible to neurodegeneration in ALS [117120]. Activation of both microglia and astrocytes occurs prominently in both human disease and animal models of ALS [121, 122]; these activated cells may contribute to motoneuron injury by releasing TNF- $\alpha[89,123]$. In this sense, TNF- $\alpha$ has been shown to potentiate AMPARmediated excitotoxicity on lumbar spinal cord motoneurons both by decreasing GLT-1 expression [86], and also by inducing a rapid membrane insertion of $\mathrm{Ca}^{2+}$ permeableAMPARs via a PI3-K and protein kinase A- (PKA-) dependent mechanism [124]. Interestingly, vascular endothelial growth factor (VEGF) has neuroprotective effects on ALS (reviewed by [125]), and it has been shown, both in vitro and in vivo, that VEGF increases the expression of GluR2 subunit of AMPARs of spinal cord motoneurons, thus minimizing their vulnerability to AMPA-mediated excitotoxicity [126].

The effects of TNF- $\alpha$ on N-methyl-D-aspartate receptors (NMDARs) trafficking are less studied; however, the results obtained are similar to those on AMPARs. Thus, in hippocampal neurons TNF- $\alpha$ induced a rapid increase in the surface expression of the NR1 subunit of NMDARs and also, via N-SMase2, promoted a specific clustering of phosphorylated NR1 subunits into lipid rafts [127]. Similarly to that described above for motoneurons, TNF- $\alpha$ has also been shown to potentiate NMDAR-mediated excitotoxicity in cortical neurons [128].

TNF- $\alpha$ also regulates inhibitory synapse function. An in vivo study in the rat spinal cord indicated that TNF- $\alpha$ increased within 60 min synaptic and total gammaaminobutyric acid A receptors $\left(\mathrm{GABA}_{\mathrm{A}} \mathrm{Rs}\right)$ in the neuropil and in the plasma membrane of motoneurons. However, the effect of TNF- $\alpha$ on $\mathrm{GABA}_{\mathrm{A}} \mathrm{R}$ trafficking was complex, displaying a nonlinear dose-dependent relationship [129]. The authors suggests that under certain physiological conditions GABAergic synapses can be excitatory and that excitatory effects of $\mathrm{GABA}_{\mathrm{A}}$ Rs have been implicated in maladaptive spinal plasticity in a model of instrumental learning [130]. Interestingly, the same group has also reported that TNF- $\alpha$ is necessary and sufficient for generating lasting inhibition of spinal learning and that the effect of this cytokine also involves $\mathrm{Ca}^{2+}$ permeable-AMPARs, since it was reverted by a GluR2-lacking AMPA receptor antagonist [131]. More recently, an in vitro study in mature rat and mouse hippocampal neurons in culture demonstrated that acute (45 min) application of TNF- $\alpha$ induced a rapid and persistent decrease of inhibitory synaptic strength as well as a downregulation of cell-surface levels of $\mathrm{GABA}_{\mathrm{A}} \mathrm{Rs}$. The trafficking of these receptors in response to TNF- $\alpha$ was mediated through the activation of neuronally expressed TNFR1 and required the activation of PI3-K, p38 MAPK, protein phosphatase 1, and dynamin GTPase [132]. 
Together, the findings presented here indicate that TNF- $\alpha$ potentiates excitotoxicity by rapidly increasing excitatory synaptic strength through increased AMPA and NMDA receptors surface expression and also that neurons respond to elevated levels of the cytokine weakening their inhibitory synaptic strength through a decreased presence of $\mathrm{GABA}_{\mathrm{A}} \mathrm{Rs}$ in the plasma membrane. Thus, the net effect of TNF- $\alpha$ is to alter the balance of excitation and inhibition resulting in a higher synaptic excitatory/inhibitory ratio [111] (Figure 1). Interestingly, it has been proposed that an elevation of this ratio is a major cause of autism spectrum disorder $[133,134]$; a pathology in that elevated levels of TNF- $\alpha$ in cerebrospinal fluid has been described [135].

\section{TNF- $\alpha$ Links Neuroinflammation and Excitotoxicity}

It is now widely accepted that most developmental, lesional, and degenerative nervous system disorders involve common interconnected neurotoxic mechanisms. Figure 1 summarizes the proposed mechanisms by which the cytokine TNF- $\alpha$ links the neuroinflammatory response to glutamate-mediated toxicity. The scheme can also be regarded as three interrelated vicious circles. The first is a microglial vicious circle in which TNF- $\alpha$ stimulates its own release. Then, it also stimulates glutamate release that acts on microglial metabotropic glutamate receptors to stimulate more TNF- $\alpha$ release. The second is an astroglial vicious circle in which TNF- $\alpha$ stimulates astrocytes to release glutamate that cannot be efficiently taken up by their glutamate transporters, thus increasing more and more the extracellular glutamate concentrations. The third is a neuronal vicious circle in which TNF- $\alpha$, by increasing the synaptic excitatory/inhibitory ratio, induces an excessive calcium entry that results in excitotoxic neuronal death; the dying neurons keep microglia in an active state that maintains their increased TNF- $\alpha$ production and release. As TNF- $\alpha$ is released by activated microglia these mechanistic links between neuroinflammation and excitotoxicity can be considered as a crosstalk between microglia and astrocytes (modulating astrocytic glutamate uptake) and microglia and neurons (modulating neuronal glutamate and GABA receptors).

It is noteworthy that the scheme shown in Figure 1 not only accounts for the most common acute or chronic neurodegenerative diseases in which increased levels of TNF- $\alpha$, associated with neuroinflammation and excitotoxicity, have been reported, but also describes a broader situation in which activated microglia releases significant amounts of TNF- $\alpha$. This is the case of opioid tolerance and neuropathic pain, two situations that are modulated by TNF- $\alpha[136,137]$. Chronic morphine exposure induces microglial activation and a significant increase in TNF- $\alpha$ mRNA expression in the rat spinal cord [138]; this effect is associated with a downregulation of GLT-1 and GLAST glutamate transporters and with an increase in the surface expression of $\mathrm{Ca}^{2+}$ permeable-AMPA and NMDA receptors [139]. All the above effects of chronic morphine, and remarkably, the loss of its antinociceptive effect, can be reverted by a TNF- $\alpha$ antagonist [138, 139]. Similarly, in mechanical allodynia, TNF- $\alpha$ mediated increased insertion of $\mathrm{Ca}^{2+}$ permeable-AMPARs in spinal cord neurons plays a major role in inflammatory pain and may represent a path by which glia contribute to neuronal sensitization and pathological pain [140].

\section{Therapy Targeting TNF- $\alpha$}

As TNF- $\alpha$ is a key mediator in the pathological mechanisms of a large number of neurological disorders including ischemia, AD, PD, MS, and ALS [3] and also in peripheral autoimmune disorders including rheumatoid and juvenile arthritis, ankylosing spondylitis, and Crohn's disease, targeting TNF- $\alpha$ action seems to be an attractive diseasemodifying strategy. The different strategies employed for TNF- $\alpha$ inhibition have been reviewed elsewhere [12] and include the use of humanized IgG antibodies (infliximab, adalimumab, and etanercept) that sequestrate sTNF- $\alpha$ and tmTNF- $\alpha$, the antibiotic minocycline that decreases TNF- $\alpha$ synthesis, the immunomodulatory drug thalidomide and its derivatives that enhance the degradation of TNF- $\alpha$ mRNA [13], and TACE inhibitors that inhibit sTNF- $\alpha$ production. Clinical trials examining the effects of TNF- $\alpha$ inhibition have been conducted on patients with MS, AD, and ALS. Although promising effects were obtained in $\mathrm{AD}$ patients with substantial cognitive and behavioral improvements [141, $142]$, the treatment failed in MS and ALS patients [143, 144]. Moreover, TNF- $\alpha$ gene knockout did not affect life span or the extent of motoneuron loss in the superoxide dismutase 1 (SOD1) transgenic mice model of ALS, thus suggesting that TNF- $\alpha$ alone is not a key factor in motoneuron degeneration [145].

The above findings can be explained first because TNF- $\alpha$ has both neuroprotective and neurotoxic effects related to the different signaling pathways activated by their receptors [146]. In this sense, mice lacking TNF- $\alpha$ receptors were more susceptible to ischemia and excitotoxic injury $[147,148]$. Second, because some proinflammatory cytokines (i.e., IL-1 $\beta$ and TNF- $\alpha$ ) have redundant functions in vivo; thus, in the TNF- $\alpha$ knockout mice an increase in the transcripts encoding for IL-1 $\beta$ was detected [145]; and, third, because TNF- $\alpha$ often works in concert with other cytokines (i.e., IFN- $\gamma$ and IL$1 \beta)$ to promote neuronal death $[66,149,150]$. Nevertheless, the identification of novel agents that can restore the normal function of activated glial cells by means of reducing the production of TNF- $\alpha$ and/or its potentiation of excitotoxicity will be essential in the management of chronic and acute neurodegenerative diseases.

\section{Conclusion}

TNF- $\alpha$ plays a physiological role in controlling synaptic transmission and plasticity in the healthy CNS by modulating ionotropic glutamate receptors trafficking. However, excessive TNF- $\alpha$ levels, as a result of different types of injury, have an inhibitory effect on glutamate transporters, resulting in increased glutamate concentration in the CNS 
parenchyma. In this context, even slight increases in TNF- $\alpha$ induced $\mathrm{Ca}^{2+}$ permeable-AMPA and/or NMDA receptors trafficking become toxic for neurons. As microglial activation and upregulation of TNF- $\alpha$ expression is a common feature of several CNS diseases, as well as chronic opioid exposure and neuropathic pain, modulating TNF- $\alpha$ signaling may represent a valuable target for intervention.

\section{Abbreviations}

A-SMase: Acidic sphingomyelinase

AD: $\quad$ Alzheimer's disease

ALS: $\quad$ Amyotrophic lateral sclerosis

AMPA: $\quad \alpha$-Amino-3-hydroxy-5-methyl-4isoxazolepropionic

AMPAR: AMPA-type glutamate receptor

CNS: $\quad$ Central nervous system

EAAT: Excitatory amino acid transporter

ERK: $\quad$ Extracellular signal-regulated kinase

$\mathrm{GABA}_{\mathrm{A}} \mathrm{R}$ : Gamma-aminobutyric acid A receptor

GLAST: Glutamate/aspartate transporter

GLT-1: Glutamate transporter 1

GluR: Glutamate receptor subunit

IFN- $\gamma$ : Interferon gamma

IFN- $\gamma$ R: Interferon gamma receptor

JNK: c-Jun N-terminal kinase

KA: $\quad$ Kainate

MEK: $\quad$ Mitogen-activated protein kinase and ERK kinase

mGluR2: Group 2 metabotropic glutamate receptor

MHC: $\quad$ Major histocompatibility complex

MS: $\quad$ Multiple sclerosis

N-SMase: Neutral sphingomyelinase

NF- $\kappa$ B: $\quad$ Nuclear factor-kappa B

NMDAR: N-methyl-D-aspartate receptor

p38 MAPK: p38 mitogen-activated protein kinase

PD: $\quad$ Parkinson's disease

PI3-K: Phosphatidylinositol 3-kinase

ROS: $\quad$ Reactive oxygen species

sTNF- $\alpha$ : Soluble TNF- $\alpha$

THA: Threohydroxyaspartate

tmTNF- $\alpha$ : Transmembrane TNF- $\alpha$

TNF- $\alpha$ : $\quad$ Tumor necrosis factor alpha

TNFR1: $\quad$ TNF- $\alpha$ receptor 1

TNRF2: $\quad$ TNF- $\alpha$ receptor 2 .

\section{Conflict of Interests}

The authors declare that there is no conflict of interests regarding the publication of this paper.

\section{Acknowledgment}

This work was supported by Grant "Programa Pont la Caixa per a grups de recerca de la UIB" to GO.

\section{References}

[1] E. A. Carswell, L. J. Old, R. L. Kassel, S. Green, N. Fiore, and B. Williamson, "An endotoxin induced serum factor that cuases necrosis of tumors," Proceedings of the National Academy of Sciences of the United States of America, vol. 72, no. 9, pp. 36663670, 1975.

[2] I. A. Clark, "How TNF was recognized as a key mechanism of disease," Cytokine and Growth Factor Reviews, vol. 18, no. 3-4, pp. 335-343, 2007.

[3] S. L. Montgomery and W. J. Bowers, "Tumor necrosis factoralpha and the roles it plays in homeostatic and degenerative processes within the central nervous system," Jounal of Neuroimmune Pharmacology, vol. 7, no. 1, pp. 42-59, 2012.

[4] M. Santello and A. Volterra, "TNFalpha in synaptic function: switching gears," Trends in Neurosciences, vol. 35, no. 10, pp. 638-647, 2012.

[5] E. C. Beattie, D. Stellwagen, W. Morishita et al., "Control of synaptic strength by glial TNF $\alpha$," Science, vol. 295, no. 5563, pp. 2282-2285, 2002.

[6] M. Kaneko, D. Stellwagen, R. C. Malenka, and M. P. Stryker, "Tumor necrosis factor- $\alpha$ mediates one component of competitive, experience-dependent plasticity in developing visual cortex," Neuron, vol. 58, no. 5, pp. 673-680, 2008.

[7] B. T. Baune, F. Wiede, A. Braun, J. Golledge, V. Arolt, and H. Koerner, "Cognitive dysfunction in mice deficient for TNFand its receptors," American Journal of Medical Genetics B: Neuropsychiatric Genetics, vol. 147, no. 7, pp. 1056-1064, 2008.

[8] C. Beste, B. T. Baune, M. Falkenstein, and C. Konrad, "Variations in the TNF- $\alpha$ gene (TNF- $\alpha-308 \mathrm{G} \rightarrow \mathrm{A}$ ) affect attention and action selection mechanisms in a dissociated fashion," Journal of Neurophysiology, vol. 104, no. 5, pp. 2523-2531, 2010.

[9] J. M. Krueger, "The role of cytokines in sleep regulation," Current Pharmaceutical Design, vol. 14, no. 32, pp. 3408-3416, 2008.

[10] C. R. Plata-Salamán, "Cytokines and feeding," International Journal of Obesity, vol. 25, supplement 5, pp. S48-S52, 2001.

[11] M. Santello, P. Bezzi, and A. Volterra, "TNF $\alpha$ controls glutamatergic gliotransmission in the hippocampal dentate gyrus," Neuron, vol. 69, no. 5, pp. 988-1001, 2011.

[12] M. K. McCoy and M. G. Tansey, "TNF signaling inhibition in the CNS: implications for normal brain function and neurodegenerative disease," Journal of Neuroinflammation, vol. 5, article 45, 2008.

[13] K. A. Frankola, N. H. Greig, W. Luo, and D. Tweedie, “Targeting TNF-alpha to elucidate and ameliorate neuroinflammation in neurodegenerative diseases," CNS and Neurological DisordersDrug Targets, vol. 10, no. 3, pp. 391-403, 2011.

[14] T. Wyss-Coray and L. Mucke, "Inflammation in neurodegenerative disease-a double-edged sword," Neuron, vol. 35, no. 3, pp. 419-432, 2002.

[15] M. Pickering, D. Cumiskey, and J. J. O'Connor, "Actions of TNF$\alpha$ on glutamatergic synaptic transmission in the central nervous system," Experimental Physiology, vol. 90, no. 5, pp. 663-670, 2005.

[16] J. C. Goodman, C. S. Robertson, R. G. Grossman, and R. K. Narayan, "Elevation of tumor necrosis factor in head injury," Journal of Neuroimmunology, vol. 30, no. 2-3, pp. 213-217, 1990.

[17] T. Liu, R. K. Clark, P. C. McDonnell et al., "Tumor necrosis factor- $\alpha$ expression in ischemic neurons," Stroke, vol. 25, no. 7, pp. 1481-1488, 1994. 
[18] G. Z. Feuerstein, T. Liu, and F. C. Barone, "Cytokines, inflammation, and brain injury: role of tumor necrosis factor-alpha," Cerebrovascular and Brain Metabolism Reviews, vol. 6, no. 4, pp. 341-360, 1994.

[19] H. Fillit, W. Ding, L. Buee et al., "Elevated circulating tumor necrosis factor levels in Alzheimer's disease," Neuroscience Letters, vol. 129, no. 2, pp. 318-320, 1991.

[20] A. Álvarez, R. Cacabelos, C. Sanpedro, M. García-Fantini, and M. Aleixandre, "Serum TNF-alpha levels are increased and correlate negatively with free IGF-I in Alzheimer disease," Neurobiology of Aging, vol. 28, no. 4, pp. 533-536, 2007.

[21] G. Boka, P. Anglade, D. Wallach, F. Javoy-Agid, Y. Agid, and E. C. Hirsch, "Immunocytochemical analysis of tumor necrosis factor and its receptors in Parkinson's disease," Neuroscience Letters, vol. 172, no. 1-2, pp. 151-154, 1994.

[22] M. Mogi, M. Harada, P. Riederer, H. Narabayashi, K. Fujita, and T. Nagatsu, "Tumor necrosis factor- $\alpha$ (TNF- $\alpha$ ) increases both in the brain and in the cerebrospinal fluid from parkinsonian patients," Neuroscience Letters, vol. 165, no. 1-2, pp. 208-210, 1994.

[23] M. K. Sharief and R. Hentges, "Association between tumor necrosis factor- $\alpha$ and disease progression in patients with multiple sclerosis," The New England Journal of Medicine, vol. 325, no. 7, pp. 467-472, 1991.

[24] P. Rieckmann, M. Albrecht, B. Kitze et al., "Tumor necrosis factor- $\alpha$ messenger RNA expression in patients with relapsingremitting multiple sclerosis is associated with disease activity," Annals of Neurology, vol. 37, no. 1, pp. 82-88, 1995.

[25] M. Poloni, D. Facchetti, R. Mai et al., "Circulating levels of tumour necrosis factor- $\alpha$ and its soluble receptors are increased in the blood of patients with amyotrophic lateral sclerosis," Neuroscience Letters, vol. 287, no. 3, pp. 211-214, 2000.

[26] G. N. Babu, A. Kumar, R. Chandra, S. K. Puri, J. Kalita, and U. K. Misra, "Elevated inflammatory markers in a group of amyotrophic lateral sclerosis patients from northern India," Neurochemical Research, vol. 33, no. 6, pp. 1145-1149, 2008.

[27] H. T. Idriss and J. H. Naismith, "TNF alpha and the TNF receptor superfamily: structure-function relationship(s)," Microscopy Research and Technique, vol. 50, no. 3, pp. 184-195, 2000.

[28] D. J. MacEwan, "TNF receptor subtype signalling: differences and cellular consequences," Cellular Signalling, vol. 14, no. 6, pp. 477-492, 2002.

[29] L. A. Tartaglia and D. V. Goeddel, "Two TNF receptors," Immunology Today, vol. 13, no. 5, pp. 151-153, 1992.

[30] B. Depuydt, G. van Loo, P. Vandenabeele, and W. Declercq, "Induction of apoptosis by TNF receptor 2 in a T-cell hybridoma is FADD dependent and blocked by caspase- 8 inhibitors," Journal of Cell Science, vol. 118, part 3, pp. 497-504, 2005.

[31] G. Chen and D. V. Goeddel, "TNF-R1 signaling: a beautiful pathway," Science, vol. 296, no. 5573, pp. 1634-1635, 2002.

[32] Z.-G. Liu and J. Han, "Cellular responses to tumor necrosis factor," Current Issues in Molecular Biology, vol. 3, no. 4, pp. 7990, 2001.

[33] H. Wajant, K. Pfizenmaier, and P. Scheurich, “Tumor necrosis factor signaling," Cell Death and Differentiation, vol. 10, no. 1, pp. 45-65, 2003.

[34] I. Y. Chung and E. N. Benveniste, "Tumor necrosis factor$\alpha$ production by astrocytes. Induction by lipopolysaccharide, IFN- $\gamma$, and IL-1 $\beta$," Journal of Immunology, vol. 144, no. 8, pp. 2999-3007, 1990.
[35] L. C. Gahring, N. G. Carlson, R. A. Kulmar, and S. W. Rogers, "Neuronal expression of tumor necrosis factor alpha in the murine brain," Neuroimmunomodulation, vol. 3, no. 5, pp. 289303, 1996.

[36] C. D. Breder, M. Tsujimoto, Y. Terano, D. W. Scott, and C. B. Saper, "Distribution and characterization of tumor necrosis factor- $\alpha$-like immunoreactivity in the murine central nervous system," Journal of Comparative Neurology, vol. 337, no. 4, pp. 543-567, 1993.

[37] J. V. Welser-Alves and R. Milner, "Microglia are the major source of TNF-alpha and TGF-betal in postnatal glial cultures, regulation by cytokines, lipopolysaccharide, and vitronectin," Neurochemistry International, vol. 63, no. 1, pp. 47-53, 2013.

[38] U.-K. Hanisch, "Microglia as a source and target of cytokines," Glia, vol. 40, no. 2, pp. 140-155, 2002.

[39] V. T. Nguyen and E. N. Benveniste, "Critical role of tumor necrosis factor- $\alpha$ and NF- $\kappa$ B in interferon- $\gamma$-induced CD 40 expression in microglia/macrophages," The Journal of Biological Chemistry, vol. 277, no. 16, pp. 13796-13803, 2002.

[40] E. N. Mangano, D. Litteljohn, R. So et al., "Interferon-gamma plays a role in paraquat-induced neurodegeneration involving oxidative and proinflammatory pathways," Neurobiology of Aging, vol. 33, no. 7, pp. 1411-1426, 2012.

[41] K. Frei, C. Siepl, P. Groscurth, S. Bodmer, C. Schwerdel, and A. Fontana, "Antigen presentation and tumor cytotoxicity by interferon- $\gamma$-treated microglial cells," European Journal of Immunology, vol. 17, no. 9, pp. 1271-1278, 1987.

[42] A. S. Harms, S. Cao, A. L. Rowse et al., "MHCII is required for alpha-synuclein-induced activation of microglia, CD4 T cell proliferation, and dopaminergic neurodegeneration," The Journal of Neuroscience, vol. 33, no. 23, pp. 9592-9600, 2013.

[43] K. Byun, J. Young Kim, E. Bayarsaikhan et al., "Quantitative proteomic analysis reveals that lipopolysaccharide induces mitogen-activated protein kinase-dependent activation in human microglial cells," Electrophoresis, vol. 33, no. 24, pp. 3756-3763, 2012.

[44] B. W. Kim, S. Koppula, S. S. Hong et al., "Regulation of microglia activity by glaucocalyxin-A: attenuation of lipopolysaccharidestimulated neuroinflammation through NF-kappaB and p38 MAPK signaling pathways," PLoS ONE, vol. 8, no. 2, Article ID e55792, 2013.

[45] R. Pangestuti, S.-S. Bak, and S.-K. Kim, "Attenuation of proinflammatory mediators in LPS-stimulated BV2 microglia by chitooligosaccharides via the MAPK signaling pathway," International Journal of Biological Macromolecules, vol. 49, no. 4, pp. 599-606, 2011.

[46] S. Zhao, L. Zhang, G. Lian et al., "Sildenafil attenuates LPSinduced pro-inflammatory responses through down-regulation of intracellular ROS-related MAPK/NF- $\kappa \mathrm{B}$ signaling pathways in N9 microglia," International Immunopharmacology, vol. 11, no. 4, pp. 468-474, 2011.

[47] M. Mir, L. Tolosa, V. J. Asensio, J. Lladó, and G. Olmos, “Complementary roles of tumor necrosis factor alpha and interferon gamma in inducible microglial nitric oxide generation," Journal of Neuroimmunology, vol. 204, no. 1-2, pp. 101-109, 2008.

[48] M. Guha, M. A. O’Connell, R. Pawlinski et al., "Lipopolysaccharide activation of the MEK-ERK1/2 pathway in human monocytic cells mediates tissue factor and tumor necrosis factor $\alpha$ expression by inducing Elk-1 phosphorylation and Egr-1 expression," Blood, vol. 98, no. 5, pp. 1429-1439, 2001. 
[49] H. A. Young and K. J. Hardy, "Role of interferon- $\gamma$ in immune cell regulation," Journal of Leukocyte Biology, vol. 58, no. 4, pp. 373-381, 1995.

[50] F. Aloisi, B. Serafini, and L. Adorini, "Glia-T cell dialogue," Journal of Neuroimmunology, vol. 107, no. 2, pp. 111-117, 2000.

[51] W. F. Hickey, B. L. Hsu, and H. Kimura, "T-lymphocyte entry into the central nervous system," Journal of Neuroscience Research, vol. 28, no. 2, pp. 254-260, 1991.

[52] A. S. Archambault, J. Sim, M. A. T. Gimenez, and J. H. Russell, "Defining antigen-dependent stages of $\mathrm{T}$ cell migration from the blood to the central nervous system parenchyma," European Journal of Immunology, vol. 35, no. 4, pp. 1076-1085, 2005.

[53] R. M. Ransohoff and B. Engelhardt, "The anatomical and cellular basis of immune surveillance in the central nervous system," Nature Reviews Immunolology, vol. 12, no. 9, pp. 623635, 2012.

[54] J. E. Merrill and E. N. Benveniste, "Cytokines in inflammatory brain lesions: helpful and harmful," Trends in Neurosciences, vol. 19, no. 8, pp. 331-338, 1996.

[55] H. Wekerle, D. Sun, R. L. Oropeza-Wekerle, and R. Meyermann, "Immune reactivity in the nervous system: modulation of Tlymphocyte activation by glial cells," Journal of Experimental Biology, vol. 132, pp. 43-57, 1987.

[56] S. H. Appel, "CD4 ${ }^{+} \mathrm{T}$ cells mediate cytotoxicity in neurodegenerative diseases," The Journal of Clinical Investigation, vol. 119, no. 1, pp. 13-15, 2009.

[57] D. Troost, J. J. van den Oord, J. M. B. V. de Jong, and D. F. Swaab, "Lymphocytic infiltration in the spinal cord of patients with amyotrophic lateral sclerosis," Clinical Neuropathology, vol. 8, no. 6, pp. 289-294, 1989.

[58] V. Brochard, B. Combadière, A. Prigent et al., "Infiltration of $\mathrm{CD} 4^{+}$lymphocytes into the brain contributes to neurodegeneration in a mouse model of Parkinson disease," The Journal of Clinical Investigation, vol. 119, no. 1, pp. 182-192, 2009.

[59] I. Medana, M. A. Martinic, H. Wekerle, and H. Neumann, "Transection of major histocompatibility complex class Iinduced neurites by cytotoxic T lymphocytes," The American Journal of Pathology, vol. 159, no. 3, pp. 809-815, 2001.

[60] R. Hohlfeld, M. Kerschensteiner, C. Stadelmann, H. Lassmann, and H. Wekerle, "The neuroprotective effect of inflammation: implications for the therapy of multiple sclerosis," Journal of Neuroimmunology, vol. 107, no. 2, pp. 161-166, 2000.

[61] M. Schwartz, I. Cohen, O. Lazarov-Spiegler, G. Moalem, and E. Yoles, "The remedy may lie in ourselves: prospects for immune cell therapy in central nervous system protection and repair," Journal of Molecular Medicine, vol. 77, no. 10, pp. 713-717, 1999.

[62] D. R. Beers, J. S. Henkel, W. Zhao, J. Wang, and S. H. Appel, "CD4 ${ }^{+} \mathrm{T}$ cells support glial neuroprotection, slow disease progression, and modify glial morphology in an animal model of inherited ALS," Proceedings of the National Academy of Sciences of the United States of America, vol. 105, no. 40, pp. 15558-15563, 2008.

[63] I. M. Chiu, A. Chen, Y. Zheng et al., "T lymphocytes potentiate endogenous neuroprotective inflammation in a mouse model of ALS," Proceedings of the National Academy of Sciences of the United States of America, vol. 105, no. 46, pp. 17913-17918, 2008.

[64] B. Liu and J.-S. Hong, "Role of microglia in inflammationmediated neurodegenerative diseases: mechanisms and strategies for therapeutic intervention," Journal of Pharmacology and Experimental Therapeutics, vol. 304, no. 1, pp. 1-7, 2003.
[65] T. Philips and W. Robberecht, "Neuroinflammation in amyotrophic lateral sclerosis: role of glial activation in motor neuron disease," The Lancet Neurology, vol. 10, no. 3, pp. 253-263, 2011.

[66] M. Mir, V. J. Asensio, L. Tolosa et al., "Tumor necrosis factor alpha and interferon gamma cooperatively induce oxidative stress and motoneuron death in rat spinal cord embryonic explants," Neuroscience, vol. 162, no. 4, pp. 959-971, 2009.

[67] J. C. Watkins and R. H. Evans, "Excitatory amino acid transmitters," Annual Review of Pharmacology and Toxicology, vol. 21, pp. 165-204, 1981.

[68] J. W. Olney, "Neurotoxicity of excitatory amino acids," in Kainic Acid as a Tool in Neurobiology, E. G. McGeer, J. W. Olney, and P. L. McGeer, Eds., pp. 95-112, Raven Press, New York, NY, USA, 1978.

[69] A. Doble, "The role of excitotoxicity in neurodegenerative disease: implications for therapy," Pharmacology and Therapeutics, vol. 81, no. 3, pp. 163-221, 1999.

[70] H. A. Gelbard, K. A. Dzenko, D. DiLoreto, C. del Cerro, M. del Cerro, and L. G. Epstein, "Neurotoxic effects of tumor necrosis factor alpha in primary human neuronal cultures are mediated by activation of the glutamate AMPA receptor subtype: implications for AIDS neuropathogenesis," Developmental Neuroscience, vol. 15, no. 6, pp. 417-422, 1993.

[71] C. C. Chao and S. Hu, "Tumor necrosis factor-alpha potentiates glutamate neurotoxicity in human fetal brain cell cultures," Developmental Neuroscience, vol. 16, no. 3-4, pp. 172-179, 1994.

[72] G. E. Hermann, R. C. Rogers, J. C. Bresnahan, and M. S. Beattie, "Tumor necrosis factor- $\alpha$ induces cFOS and strongly potentiates glutamate-mediated cell death in the rat spinal cord," Neurobiology of Disease, vol. 8, no. 4, pp. 590-599, 2001.

[73] H. Takeuchi, S. Jin, J. Wang et al., "Tumor necrosis factor- $\alpha$ induces neurotoxicity via glutamate release from hemichannels of activated microglia in an autocrine manner," The Journal of Biological Chemistry, vol. 281, no. 30, pp. 21362-21368, 2006.

[74] D. L. Taylor, F. Jones, E. S. F. Chen Seho Kubota, and J. M. Pocock, "Stimulation of microglial metabotropic glutamate receptor mGlu2 triggers tumor necrosis factor $\alpha$-induced neurotoxicity in concert with microglial-derived Fas ligand," The Journal of Neuroscience, vol. 25, no. 11, pp. 2952-2964, 2005.

[75] W. Zhu, H. Zheng, X. Shao, W. Wang, Q. Yao, and Z. Li, "Excitotoxicity of TNF $\alpha$ derived from KA activated microglia on hippocampal neurons in vitro and in vivo," Journal of Neurochemistry, vol. 114, no. 2, pp. 386-396, 2010.

[76] R. Kuno, J. Wang, J. Kawanokuchi, H. Takeuchi, T. Mizuno, and A. Suzumura, "Autocrine activation of microglia by tumor necrosis factor- $\alpha$," Journal of Neuroimmunology, vol. 162, no. 1-2, pp. 89-96, 2005.

[77] P. Bezzi, M. Domercq, L. Brambilla et al., "CXCR4-activated astrocyte glutamate release via TNFa: amplification by microglia triggers neurotoxicity," Nature Neuroscience, vol. 4, no. 7, pp. 702-710, 2001.

[78] P. Bezzi, G. Carmignoto, L. Pasti et al., "Prostaglandins stimulate calcium-dependent glutamate release in astrocytes," Nature, vol. 391, no. 6664, pp. 281-285, 1998.

[79] G. Gegelashvili and A. Schousboe, "High affinity glutamate transporters: regulation of expression and activity", Molecular Pharmacology, vol. 52, no. 1, pp. 6-15, 1997.

[80] Y. Zhou and N. C. Danbolt, "GABA and glutamate transporters in brain," Frontiers in Endocrinology, vol. 4, Article ID 165, 2013.

[81] S. Tilleux and E. Hermans, "Neuroinflammation and regulation of glial glutamate uptake in neurological disorders," Journal of Neuroscience Research, vol. 85, no. 10, pp. 2059-2070, 2007. 
[82] N. C. Danbolt, "Purification and reconstitution of the sodiumand potassium-coupled glutamate transport glycoprotein from rat brain," Biochemistry, vol. 29, no. 28, pp. 6734-6740, 1990.

[83] N. C. Danbolt, "Glutamate uptake," Progress in Neurobiology, vol. 65, no. 1, pp. 1-105, 2001.

[84] R. Sitcheran, P. Gupta, P. B. Fisher, and A. S. Baldwin, "Positive and negative regulation of EAAT2 by NF- $\kappa$ B: a role for N-myc in TNF $\alpha$-controlled repression," The EMBO Journal, vol. 24, no. 3, pp. 510-520, 2005.

[85] Z. Wang, O. Pekarskaya, M. Bencheikh et al., "Reduced expression of glutamate transporter EAAT2 and impaired glutamate transport in human primary astrocytes exposed to HIV-1 or gp120," Virology, vol. 312, no. 1, pp. 60-73, 2003.

[86] L. Tolosa, V. Caraballo-Miralles, G. Olmos, and J. Lladó, “TNF$\alpha$ potentiates glutamate-induced spinal cord motoneuron death via NF- $\kappa$ B," Molecular and Cellular Neuroscience, vol. 46, no. 1 , pp. 176-186, 2011.

[87] J. Y. Zou and F. T. Crews, "TNF $\alpha$ potentiates glutamate neurotoxicity by inhibiting glutamate uptake in organotypic brain slice cultures: neuroprotection by NF $\kappa$ B inhibition," Brain Research, vol. 1034, no. 1-2, pp. 11-24, 2005.

[88] K. Hensley, M. Mhatre, S. Mou et al., "On the relation of oxidative stress to neuroinflammation: lessons learned from the G93A-SOD1 mouse model of amyotrophic lateral sclerosis," Antioxidants \& Redox Signaling, vol. 8, no. 11-12, pp. 2075-2087, 2006.

[89] M. Mhatrea, R. A. Floyd, and K. Hensley, "Oxidative stress and neuroinflammation in Alzheimer's disease and amyotrophic lateral sclerosis: common links and potential therapeutic targets," Journal of Alzheimer's Disease, vol. 6, no. 2, pp. 147-157, 2004.

[90] D. Trotti, N. C. Danbolt, and A. Volterra, "Glutamate transporters are oxidant-vulnerable: a molecular link between oxidative and excitotoxic neurodegeneration?" Trends in Pharmacological Sciences, vol. 19, no. 8, pp. 328-334, 1998.

[91] V. J. Miralles, I. Martínez-López, R. Zaragozá et al., "Na ${ }^{+}$dependent glutamate transporters (EAAT1, EAAT2, and EAAT3) in primary astrocyte cultures: effect of oxidative stress," Brain Research, vol. 922, no. 1, pp. 21-29, 2001.

[92] S. D. Rao, H. Z. Yin, and J. H. Weiss, "Disruption of glial glutamate transport by reactive oxygen species produced in motor neurons," Journal of Neuroscience, vol. 23, no. 7, pp. 26272633, 2003.

[93] P. Pasinelli, M. K. Houseweart, R. H. Brown Jr., and D. W. Cleveland, "Caspase- 1 and -3 are sequentially activated in motor neuron death in $\mathrm{Cu}, \mathrm{Zn}$ superoxide dismutase-mediated familial amyotrophic lateral sclerosis," Proceedings of the National Academy of Sciences of the United States of America, vol. 97, no. 25, pp. 13901-13906, 2000.

[94] W. Boston-Howes, S. L. Gibb, E. O. Williams, P. Pasinelli, R. H. Brown Jr., and D. Trotti, "Caspase- 3 cleaves and inactivates the glutamate transporter EAAT2," The Journal of Biological Chemistry, vol. 281, no. 20, pp. 14076-14084, 2006.

[95] L. van den Bosch, P. van Damme, E. Bogaert, and W. Robberecht, "The role of excitotoxicity in the pathogenesis of amyotrophic lateral sclerosis," Biochimica et Biophysica Acta, vol. 1762, no. 11-12, pp. 1068-1082, 2006.

[96] J. D. Rothstein, M. van Kammen, A. I. Levey, L. J. Martin, and R. W. Kuncl, "Selective loss of glial glutamate transporter GLT-1 amyotrophic lateral sclerosis," Annals of Neurology, vol. 38, no. 1, pp. 73-84, 1995.

[97] L. I. Bruijn, M. W. Becher, M. K. Lee et al., "ALS-linked SOD1 mutant G85R mediates damage to astrocytes and promotes rapidly progressive disease with SOD1-containing inclusions," Neuron, vol. 18, no. 2, pp. 327-338, 1997.

[98] D. S. Howland, J. Liu, Y. She et al., "Focal loss of the glutamate transporter EAAT2 in a transgenic rat model of SOD1 mutantmediated amyotrophic lateral sclerosis (ALS)," Proceedings of the National Academy of Sciences of the United States of America, vol. 99, no. 3, pp. 1604-1609, 2002.

[99] K. Shobha, K. Vijayalakshmi, P. A. Alladi, A. Nalini, T. N. Sathyaprabha, and T. R. Raju, "Altered in-vitro and in-vivo expression of glial glutamate transporter-1 following exposure to cerebrospinal fluid of amyotrophic lateral sclerosis patients," Journal of the Neurological Sciences, vol. 254, no. 1-2, pp. 9-16, 2007.

[100] S. Nakanishi, "Molecular diversity of glutamate receptors and implications for brain function," Science, vol. 258, no. 5082, pp. 597-603, 1992.

[101] P. H. Seeburg, “The TINS/TiPS lecture: the molecular biology of mammalian glutamate receptor channels," Trends in Neurosciences, vol. 16, no. 9, pp. 359-365, 1993.

[102] S.-H. Shi, Y. Hayashi, J. A. Esteban, and R. Malinow, "Subunitspecific rules governing AMPA receptor trafficking to synapses in hippocampal pyramidal neurons," Cell, vol. 105, no. 3, pp. 331343, 2001.

[103] M. S. Beattie, A. R. Ferguson, and J. C. Bresnahan, "AMPAreceptor trafficking and injury-induced cell death," The European Journal of Neuroscience, vol. 32, no. 2, pp. 290-297, 2010.

[104] G. G. Turrigiano, "The self-tuning neuron: synaptic scaling of excitatory synapses," Cell, vol. 135, no. 3, pp. 422-435, 2008.

[105] M. Hollmann, M. Hartley, and S. Heinemann, " $\mathrm{Ca}^{2+}$ permeability of KA-AMPA - gated glutamate receptor channels depends on subunit composition," Science, vol. 252, no. 5007, pp. 851-853, 1991.

[106] T. A. Verdoorn, N. Burnashev, H. Monyer, P. H. Seeburg, and B. Sakmann, "Structural determinants of ion flow through recombinant glutamate receptor channels," Science, vol. 252, no. 5013, pp. 1715-1718, 1991.

[107] D. E. Pellegrini-Giampietro, J. A. Gorter, M. V. Bennett, and R. S. Zukin, "The GluR2 (GluR-B) hypothesis: $\mathrm{Ca}^{2+}$-permeable AMPA receptors in neurological disorders," Trends in Neurosciences, vol. 20, no. 10, pp. 464-470, 1997.

[108] J. H. Weiss and S. L. Sensi, " $\mathrm{Ca}^{2+}-\mathrm{Zn}^{2+}$ permeable AMPA or kainate receptors: possible key factors in selective neurodegeneration," Trends in Neurosciences, vol. 23, no. 8, pp. 365-371, 2000.

[109] Z. Yu, G. Cheng, X. Wen, G. D. Wu, W.-T. Lee, and D. Pleasure, "Tumor necrosis factor $\alpha$ increases neuronal vulnerability to excitotoxic necrosis by inducing expression of the AMPA-glutamate receptor subunit GluR1 via an acid sphingomyelinase-and NF- $\kappa$ B-dependent mechanism," Neurobiology of Disease, vol. 11, no. 1, pp. 199-213, 2002.

[110] L. Bernardino, S. Xapelli, A. P. Silva et al., "Modulator effects of interleukin- $1 \beta$ and tumor necrosis factor- $\alpha$ on AMPAinduced excitotoxicity in mouse organotypic hippocampal slice cultures," The Journal of Neuroscience, vol. 25, no. 29, pp. 67346744, 2005.

[111] D. Stellwagen, E. C. Beattie, J. Y. Seo, and R. C. Malenka, "Differential regulation of AMPA receptor and GABA receptor trafficking by tumor necrosis factor- $\alpha$," The Journal of Neuroscience, vol. 25, no. 12, pp. 3219-3228, 2005.

[112] D. Leonoudakis, P. Zhao, and E. C. Beattie, "Rapid tumor necrosis factor $\alpha$-induced exocytosis of glutamate receptor 2lacking AMPA receptors to extrasynaptic plasma membrane 
potentiates excitotoxicity," The Journal of Neuroscience, vol. 28, no. 9, pp. 2119-2130, 2008.

[113] F. Ogoshi, H. Z. Yin, Y. Kuppumbatti, B. Song, S. Amindari, and J. H. Weiss, "Tumor necrosis-factor-alpha (TNF$\alpha$ ) induces rapid insertion of $\mathrm{Ca}^{2+}$-permeable $\alpha$-amino-3hydroxyl-5-methyl-4-isoxazole- propionate (AMPA)/kainate (Ca-A/K) channels in a subset of hippocampal pyramidal neurons," Experimental Neurology, vol. 193, no. 2, pp. 384-393, 2005.

[114] A. R. Ferguson, R. N. Christensen, J. C. Gensel et al., "Cell death after spinal cord injury is exacerbated by rapid TNF $\alpha$ induced trafficking of GluR2-lacking AMPARs to the plasma membrane," The Journal of Neuroscience, vol. 28, no. 44, pp. 11391-11400, 2008.

[115] P. Han and P. J. Whelan, "Tumor necrosis factor alpha enhances glutamatergic transmission onto spinal motoneurons," Journal of Neurotrauma, vol. 27, no. 1, pp. 287-292, 2010.

[116] S. R. Rainey-Smith, D. A. Andersson, R. J. Williams, and M. Rattray, "Tumour necrosis factor alpha induces rapid reduction in AMPA receptor-mediated calcium entry in motor neurones by increasing cell surface expression of the GluR2 subunit: relevance to neurodegeneration," Journal of Neurochemistry, vol. 113, no. 3, pp. 692-703, 2010.

[117] T. L. Williams, N. C. Day, P. G. Ince, R. K. Kamboj, and P. J. Shaw, "Calcium-permeable alpha-amino-3-hydroxy-5-methyl4-isoxazole propionic acid receptors: a molecular determinant of selective vulnerability in amyotrophic lateral sclerosis," Annals of Neurology, vol. 42, no. 2, pp. 200-207, 1997.

[118] H. Z. Yin, D. T. Tang, and J. H. Weiss, "Intrathecal infusion of a $\mathrm{Ca}^{2+}$-permeable AMPA channel blocker slows loss of both motor neurons and of the astrocyte glutamate transporter, GLT1 in a mutant SOD1 rat model of ALS," Experimental Neurology, vol. 207, no. 2, pp. 177-185, 2007.

[119] M. Tateno, H. Sadakata, M. Tanaka et al., "Calcium-permeable AMPA receptors promote misfolding of mutant SOD1 protein and development of amyotrophic lateral sclerosis in a transgenic mouse model," Human Molecular Genetics, vol. 13, no. 19, pp. 2183-2196, 2004.

[120] J. C. Corona and R. Tapia, " $\mathrm{Ca}^{2+}$-permeable AMPA receptors and intracellular $\mathrm{Ca}^{2+}$ determine motoneuron vulnerability in rat spinal cord in vivo," Neuropharmacology, vol. 52, no. 5, pp. 1219-1228, 2007.

[121] S. A. Sargsyan, P. N. Monk, and P. J. Shaw, "Microglia as potential contributors to motor neuron injury in amyotrophic lateral sclerosis," Glia, vol. 51, no. 4, pp. 241-253, 2005.

[122] L. H. Barbeito, M. Pehar, P. Cassina et al., "A role for astrocytes in motor neuron loss in amyotrophic lateral sclerosis," Brain Research Reviews, vol. 47, no. 1-3, pp. 263-274, 2004.

[123] D. Tweedie, K. Sambamurti, and N. H. Greig, "TNF- $\alpha$ inhibition as a treatment strategy for neurodegenerative disorders: new drug candidates and targets," Current Alzheimer Research, vol. 4, no. 4, pp. 378-385, 2007.

[124] H. Z. Yin, C. I. Hsu, S. Yu, S. D. Rao, L. S. Sorkin, and J. H. Weiss, "TNF-alpha triggers rapid membrane insertion of $\mathrm{Ca}^{2+}$ permeable AMPA receptors into adult motor neurons and enhances their susceptibility to slow excitotoxic injury," Experimental Neurology, vol. 238, no. 2, pp. 93-102, 2012.

[125] J. Llado, L. Tolosa, and G. Olmos, "Cellular and molecular mechanisms involved in the neuroprotective effects of VEGF on motoneurons," Frontiers in Cellular Neuroscience, vol. 7, Article ID 181, 2013.
[126] E. Bogaert, P. van Damme, K. Poesen et al., "VEGF protects motor neurons against excitotoxicity by upregulation of GluR2," Neurobiology of Aging, vol. 31, no. 12, pp. 2185-2191, 2010.

[127] D. Wheeler, E. Knapp, V. V. R. Bandaru et al., "Tumor necrosis factor- $\alpha$-induced neutral sphingomyelinase- 2 modulates synaptic plasticity by controlling the membrane insertion of NMDA receptors," Journal of Neurochemistry, vol. 109, no. 5, pp. 1237-1249, 2009.

[128] A. M. Floden, S. Li, and C. K. Combs, “ $\beta$-Amyloid-stimulated microglia induce neuron death via synergistic stimulation of tumor necrosis factor $\alpha$ and NMDA receptors," The Journal of Neuroscience, vol. 25, no. 10, pp. 2566-2575, 2005.

[129] E. D. Stück, R. N. Christensen, J. R. Huie et al., “Tumor necrosis factor alpha mediates GABAA receptor trafficking to the plasma membrane of spinal cord neurons in vivo," Neural Plasticity, vol. 2012, Article ID 261345, 2012.

[130] A. R. Ferguson, S. N. Washburn, E. D. Crown, and J. W. Grau, "GABAA receptor activation is involved in noncontingent shock inhibition of instrumental conditioning in spinal rats," Behavioral Neuroscience, vol. 117, no. 4, pp. 799-812, 2003.

[131] J. R. Huie, K. M. Baumbauer, K. H. Lee et al., "Glial tumor necrosis factor alpha (TNFalpha) generates metaplastic inhibition of spinal learning," PLoS ONE, vol. 7, no. 6, Article ID e39751, 2012.

[132] H. Pribiag and D. Stellwagen, "TNF-alpha downregulates inhibitory neurotransmission through protein phosphatase 1dependent trafficking of $\mathrm{GABA}_{\mathrm{A}}$ receptors," The Journal of Neuroscience, vol. 33, no. 40, pp. 15879-15893, 2013.

[133] J. L. R. Rubenstein and M. M. Merzenich, "Model of autism: increased ratio of excitation/inhibition in key neural systems," Genes, Brain and Behavior, vol. 2, no. 5, pp. 255-267, 2003.

[134] O. Yizhar, L. E. Fenno, M. Prigge et al., "Neocortical excitation/inhibition balance in information processing and social dysfunction," Nature, vol. 477, no. 7363, pp. 171-178, 2011.

[135] M. G. Chez, T. Dowling, P. B. Patel, P. Khanna, and M. Kominsky, "Elevation of tumor necrosis factor-alpha in cerebrospinal fluid of autistic children," Pediatric Neurology, vol. 36, no. 6, pp. 361-365, 2007.

[136] Y.-R. Wen, P.-H. Tan, J.-K. Cheng, Y.-C. Liu, and R.-R. Ji, "Microglia: a promising target for treating neuropathic and postoperative pain, and morphine tolerance," Journal of the Formosan Medical Association, vol. 110, no. 8, pp. 487-494, 2011.

[137] C.-H. Shen, R.-Y. Tsai, and C.-S. Wong, "Role of neuroinflammation in morphine tolerance: effect of tumor necrosis factoralpha," Acta Anaesthesiologica Taiwanica, vol. 50, no. 4, pp. 178$182,2012$.

[138] C.-H. Shen, R.-Y. Tsai, M.-S. Shih et al., "Etanercept restores the antinociceptive effect of morphine and suppresses spinal neuroinflammation in morphine-tolerant rats," Anesthesia and Analgesia, vol. 112, no. 2, pp. 454-459, 2011.

[139] C.-H. Shen, R.-Y. Tsai, Y.-H. Tai, S.-L. Lin, C.-C. Chien, and C.S. Wong, "Intrathecal etanercept partially restores morphines antinociception in morphine-tolerant rats via attenuation of the glutamatergic transmission," Anesthesia and Analgesia, vol. 113, no. 1, pp. 184-190, 2011.

[140] J. I. Choi, C. I. Svensson, F. J. Koehrn, A. Bhuskute, and L. S. Sorkin, "Peripheral inflammation induces tumor necrosis factor dependent AMPA receptor trafficking and Akt phosphorylation in spinal cord in addition to pain behavior," Pain, vol. 149, no. 2, pp. 243-253, 2010.

[141] E. L. Tobinick and H. Gross, "Rapid improvement in verbal fluency and aphasia following perispinal etanercept in Alzheimer's disease," BMC Neurology, vol. 8, article 27, 2008. 
[142] E. Tobinick, H. Gross, A. Weinberger, and H. Cohen, "TNFalpha modulation for treatment of Alzheimer's disease: a 6month pilot study," Medscape General Medicine, vol. 8, no. 2, article 25, 2006.

[143] B. W. van Oosten, F. Barkhof, L. Truyen et al., "Increased MRI activity and immune activation in two multiple sclerosis patients treated with the monoclonal anti-tumor necrosis factor antibody cA2," Neurology, vol. 47, no. 6, pp. 1531-1534, 1996.

[144] E. W. Stommel, J. A. Cohen, C. E. Fadul et al., "Efficacy of thalidomide for the treatment of amyotrophic lateral sclerosis: a phase II open label clinical trial," Amyotrophic Lateral Sclerosis, vol. 10, no. 5-6, pp. 393-404, 2009.

[145] G. Gowing, F. Dequen, G. Soucy, and J.-P. Julien, "Absence of tumor necrosis factor- $\alpha$ does not affect motor neuron disease caused by superoxide dismutase 1 mutations," The Journal of Neuroscience, vol. 26, no. 44, pp. 11397-11402, 2006.

[146] P. Ghezzi and T. Mennini, "Tumor necrosis factor and motoneuronal degeneration: an open problem," NeuroImmunomodulation, vol. 9, no. 4, pp. 178-182, 2001.

[147] A. J. Bruce, W. Boling, M. S. Kindy et al., "Altered neuronal and microglial responses to excitotoxic and ischemic brain injury in mice lacking TNF receptors," Nature Medicine, vol. 2, no. 7, pp. 788-794, 1996.

[148] P. G. Sullivan, A. J. Bruce-Keller, A. G. Rabchevsky et al., "Exacerbation of damage and altered NF- $\kappa$ B activation in mice lacking tumor necrosis factor receptors after traumatic brain injury," The Journal of Neuroscience, vol. 19, no. 15, pp. 62486256, 1999.

[149] G.-H. Jeohn, L.-Y. Kong, B. Wilson, P. Hudson, and J.-S. Hong, "Synergistic neurotoxic effects of combined treatments with cytokines in murine primary mixed neuron/glia cultures," Journal of Neuroimmunology, vol. 85, no. 1, pp. 1-10, 1998.

[150] C. C. Chao, S. Hu, L. Ehrlich, and P. K. Peterson, "Interleukin-1 and tumor necrosis factor- $\alpha$ synergistically mediate neurotoxicity: Involvement of nitric oxide and of N-methyl-D-aspartate receptors," Brain, Behavior, and Immunity, vol. 9, no. 4, pp. 355$365,1995$. 


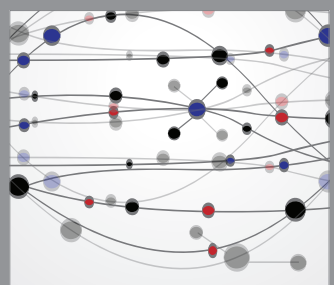

The Scientific World Journal
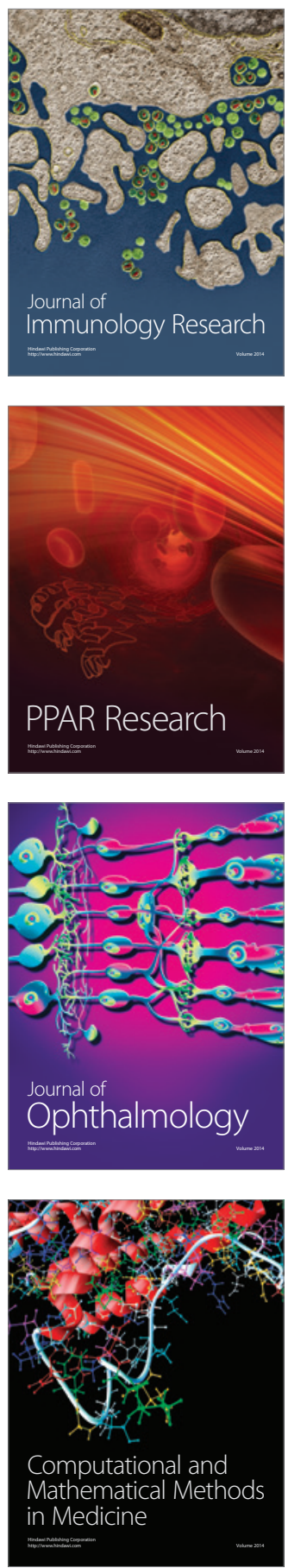

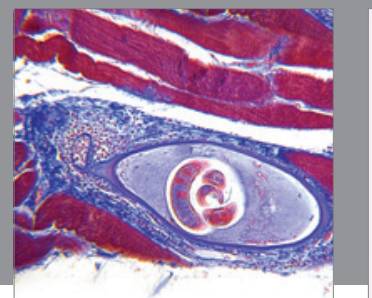

Gastroenterology

Research and Practice
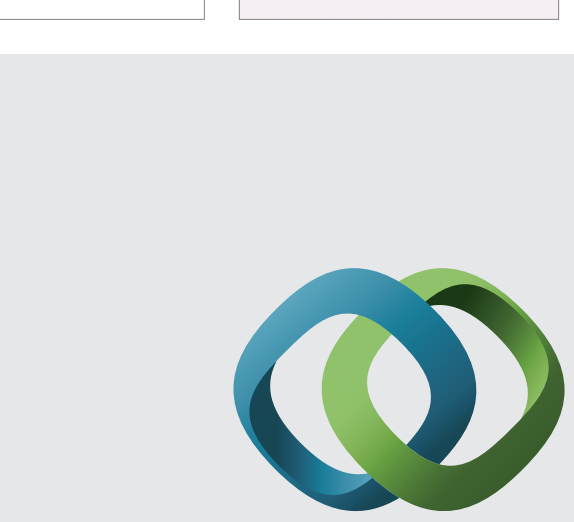

\section{Hindawi}

Submit your manuscripts at

http://www.hindawi.com
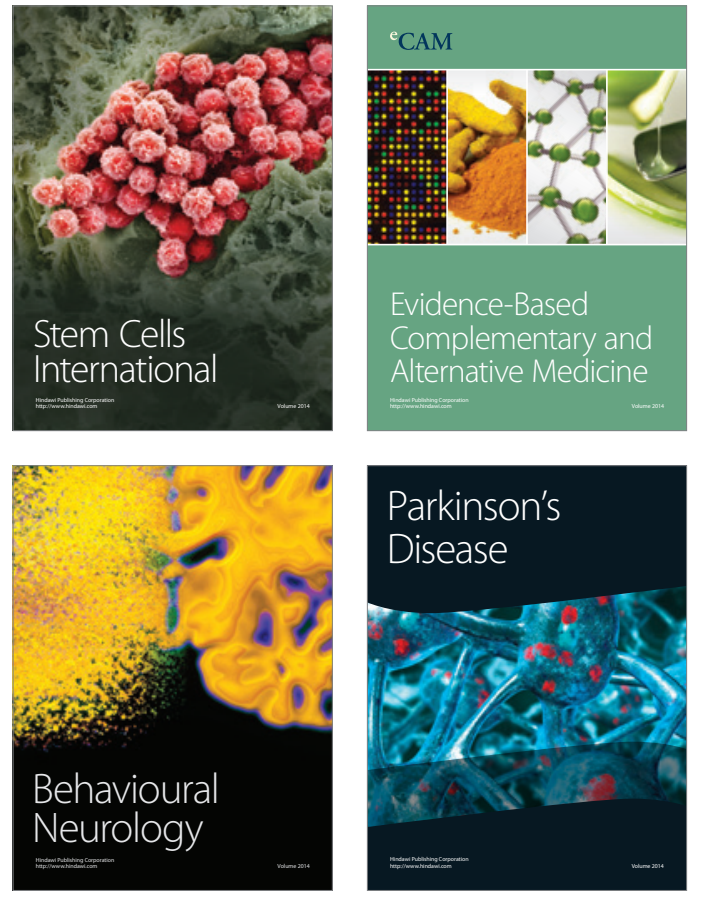
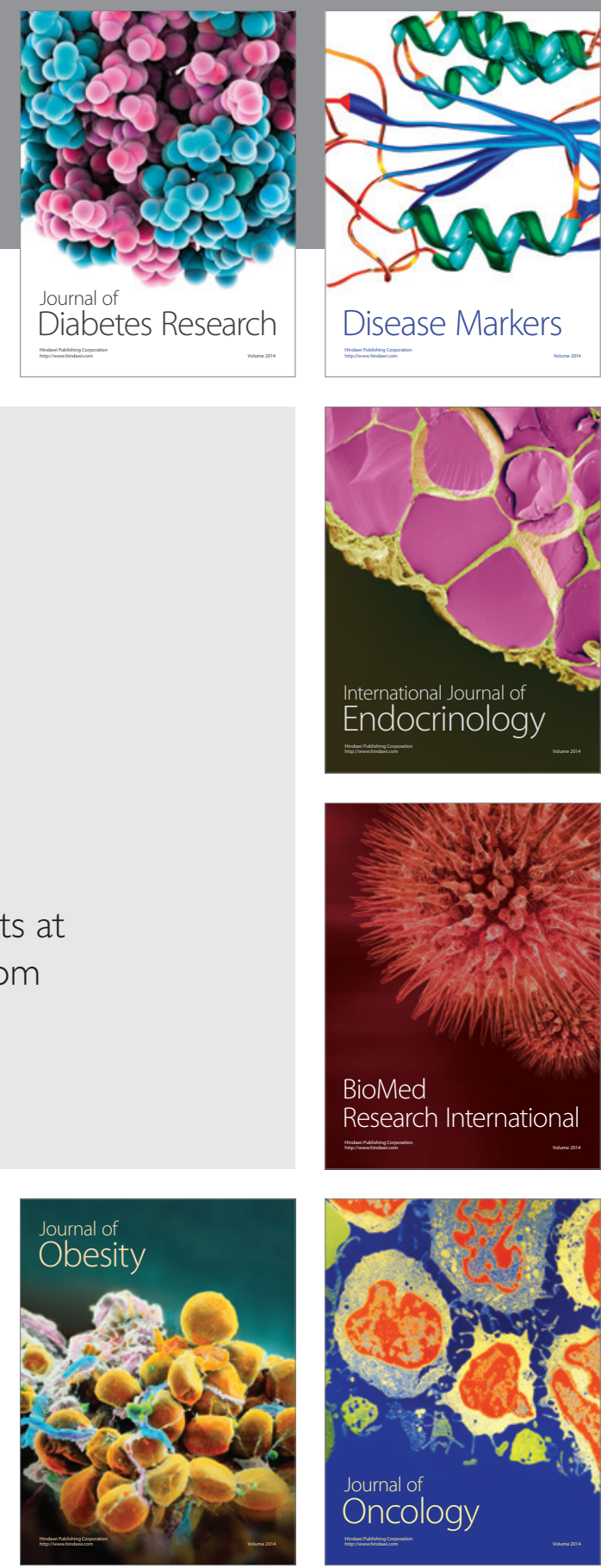

Disease Markers
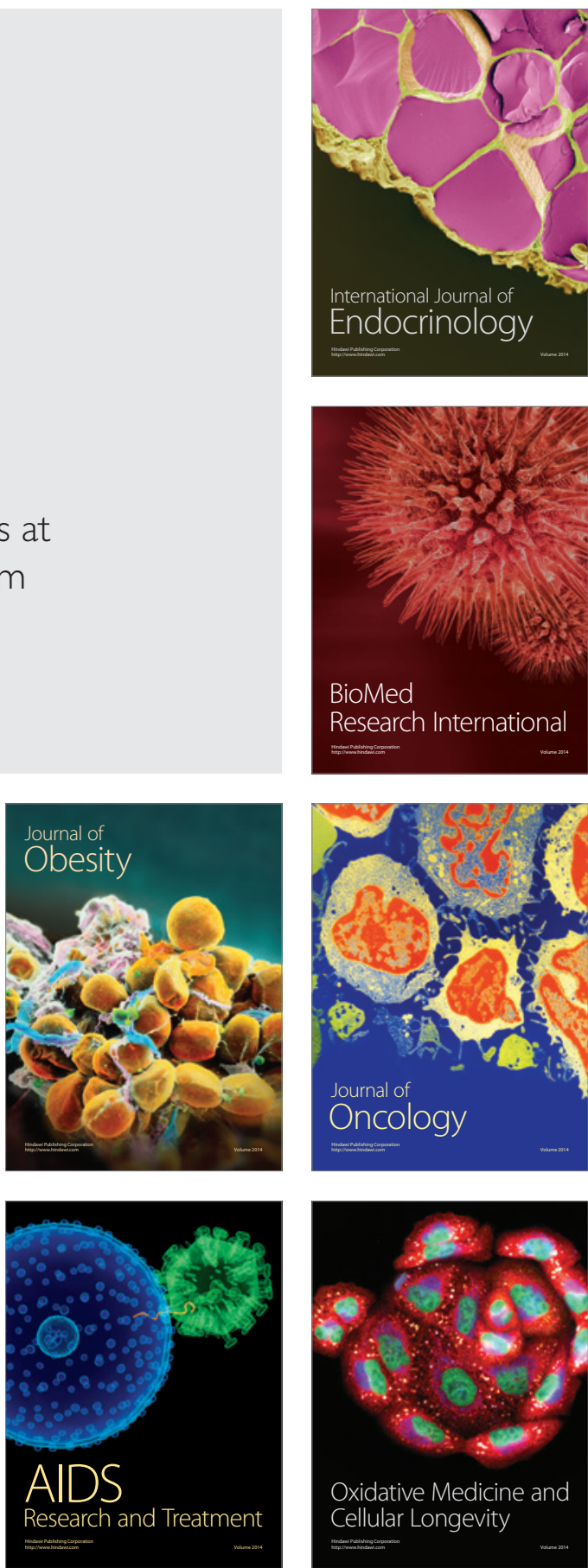